\title{
Freeze Damage of Carinata Grown in the Southeastern US ${ }^{1}$
}

\author{
Michael J. Mulvaney, Mahesh Bashyal, Joseph E. Iboyi, Ramdeo Seepaul, Pratap Devkota, lan \\ Small, David Wright ${ }^{2}$
}

Brassica carinata, sometimes called Ethiopian mustard, Abyssinian mustard, or simply carinata, is an annual oilseed crop used for the commercial production of jet fuel. It is similar to canola in growth habit. Carinata by-products include seed meal for animal feed (Agrisoma 2017) and sinapic acid for organic and polymer synthesis (Shen 2019), and the residue may act as a bio-suppressant against nematodes (Oka 2010). It is grown during the winter in the southeastern United States and may have potential as an alternative winter crop for the region.

One of the challenges to commercialization of this crop in the region has been freeze damage. Since the crop is planted in late fall, temperatures can sometimes fluctuate between $50^{\circ} \mathrm{F}\left(10^{\circ} \mathrm{C}\right)$ during the day to $20^{\circ} \mathrm{F}\left(-6.7^{\circ} \mathrm{C}\right)$ that same night as a front moves through, giving the crop little time to harden off. Susceptibility to freeze damage depends on temperature, duration at a given temperature, crop growth stage, and nitrogen application rates. Genotype screening trials throughout the Southeast are underway to identify freeze-tolerant cultivars.

This publication serves as a guide to assess freeze damage and discuss management issues related to freeze damage of carinata in the southeastern United States for growers,
Extension agents, researchers, crop consultants, and agricultural professionals. Be aware that this is a relatively new crop to the Southeast and research on this topic is ongoing. This publication represents the latest information available. More information about carinata production in Florida is available from Seepaul et al. (2019) at https://edis. ifas.ufl.edu/publication/AG389.

\section{Symptomology}

The severity of freeze damage largely depends on the crop stage. At the seedling stage when roots are shallow and there are few carbohydrate reserves, freeze can kill the crop. At the rosette stage, leaves protect the growing point and roots are deeper, resulting in greater freeze tolerance, although leaf tissue damage can occur. After bolting, the stalk and growing points are most susceptible to freeze damage. Stalk damage typically results in tissue damage several inches above the soil surface, where structural stresses are high. Death of the growing point commonly results in new shoot growth from the crown of the plant or from just below the damaged tissue after bolting.

1. This document is SS-AGR-420, one of a series of the Agronomy Department, UF/IFAS Extension. Original publication date May 2018. Revised July 2021. Visit the EDIS website at https://edis.ifas.ufl.edu for the currently supported version of this publication.

2. Michael J. Mulvaney, associate professor, cropping systems specialist, Agronomy Department, UF/IFAS West Florida Research and Education Center; Mahesh Bashyal, graduate research assistant, Agronomy Department, UF/IFAS WFREC; Joseph E. Iboyi, graduate research assistant, Agronomy Department, UF/IFAS WFREC; Ramdeo Seepaul, assistant research scientist, Agronomy Department, UF/IFAS North Florida Research and Education Center; Pratap Devkota, assistant professor, weed science, UF/IFAS WFREC; lan Small, assistant professor, plant pathology, UF/IFAS NFREC; and David Wright, Extension specialist, cropping systems and conservation tillage, and professor, Agronomy Department, UF/IFAS NFREC; UF/IFAS Extension, Gainesville, FL 32611.

The Institute of Food and Agricultural Sciences (IFAS) is an Equal Opportunity Institution authorized to provide research, educational information and other services

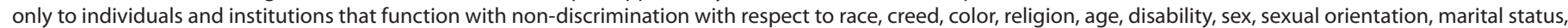

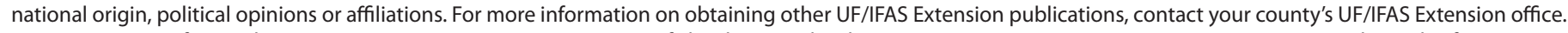
U.S. Department of Agriculture, UF/IFAS Extension Service, University of Florida, IFAS, Florida A \& M University Cooperative Extension Program, and Boards of County Commissioners Cooperating. Nick T. Place, dean for UF/IFAS Extension. 
Minor freeze damage first appears as wilting. Within about one week, symptoms present as bleaching of the leaves, particularly near the tips and leaf margins (Figure 1). If freeze damage is more severe, these areas may become necrotic, but the crop is expected to outgrow this level of damage with minimal yield loss (Figure 2).

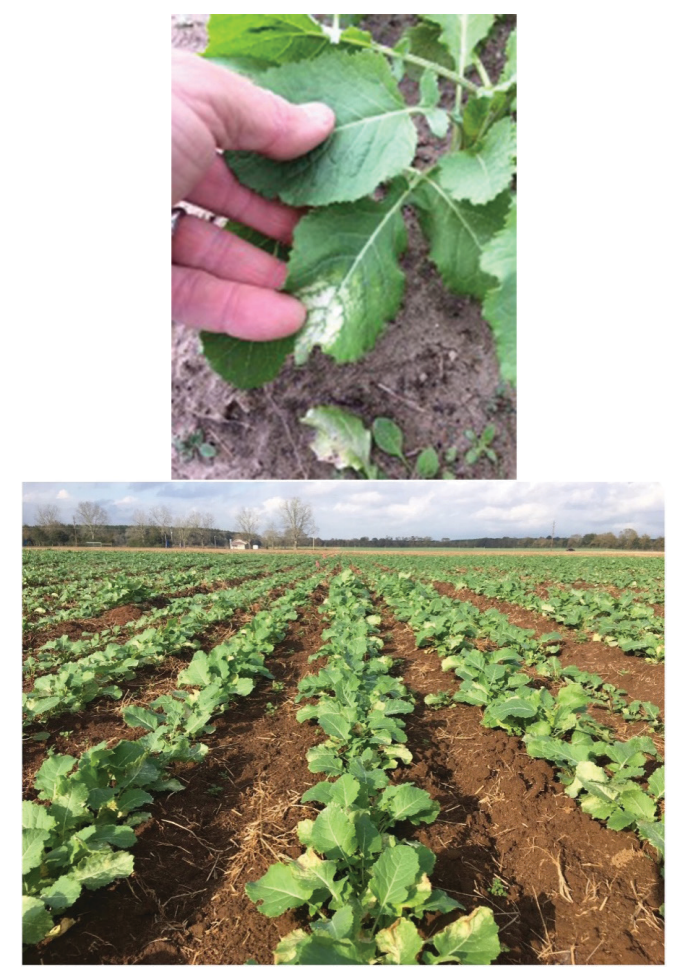

Figure 1. Leaf bleaching is typically evident 1-2 weeks after a freeze event in carinata at the rosette stage. The crop will outgrow this level of damage. UF/IFAS West Florida Research and Education Center, Jay, FL.

Credits: M. J. Mulvaney, UF/IFAS

Table 1. Cumulative hours below temperature thresholds four weeks prior to the date the photos in Figure 1 were taken.

\begin{tabular}{|l|l|}
\hline Planted: & 2-Nov-2017 \\
\hline Photo taken: & 20-Dec-2017 \\
\hline Temperature & Cumulative Hours Below \\
\hline $32^{\circ} \mathrm{F}\left(0^{\circ} \mathrm{C}\right)$ & 30.5 \\
\hline $25^{\circ} \mathrm{F}\left(-3.9^{\circ} \mathrm{C}\right)$ & 0.0 \\
\hline $20^{\circ} \mathrm{F}\left(-6.7^{\circ} \mathrm{C}\right)$ & 0.0 \\
\hline $15^{\circ} \mathrm{F}\left(-9.4^{\circ} \mathrm{C}\right)$ & 0.0 \\
\hline
\end{tabular}

Figure 3 shows severe cold damage. This level of damage is expected to reduce crop stands and yield. Note that the aboveground tissue was severely affected, but the roots did not die. The plants in Figure 3 grew back from the growing point, but can also be expected to resprout from the crown if the roots did not freeze. Replanting of this field is not recommended due to lateness and expected continued crop growth.

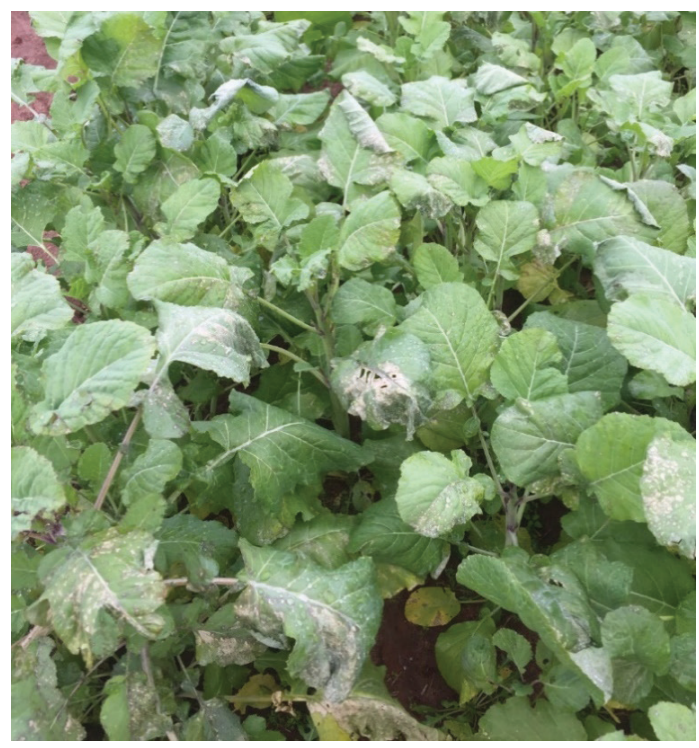

Figure 2. Tissue affected by cold damage may become necrotic. The crop will outgrow this level of damage. UF/IFAS West Florida Research and Education Center, Jay, FL.

Credits: M. J. Mulvaney, UF/IFAS

Table 2. Cumulative hours below temperature threshold four weeks prior to the date the photo in Figure 2 was taken.

\begin{tabular}{|l|l|}
\hline Planted: & 23-Nov-2015 \\
\hline Photo taken: & 8-Jan-2016 \\
\hline Temperature & Cumulative Hours Below \\
\hline $32^{\circ} \mathrm{F}\left(0^{\circ} \mathrm{C}\right)$ & 10.3 \\
\hline $25^{\circ} \mathrm{F}\left(-3.9^{\circ} \mathrm{C}\right)$ & 0.0 \\
\hline $20^{\circ} \mathrm{F}\left(-6.7^{\circ} \mathrm{C}\right)$ & 0.0 \\
\hline $15^{\circ} \mathrm{F}\left(-9.4^{\circ} \mathrm{C}\right)$ & 0.0 \\
\hline
\end{tabular}

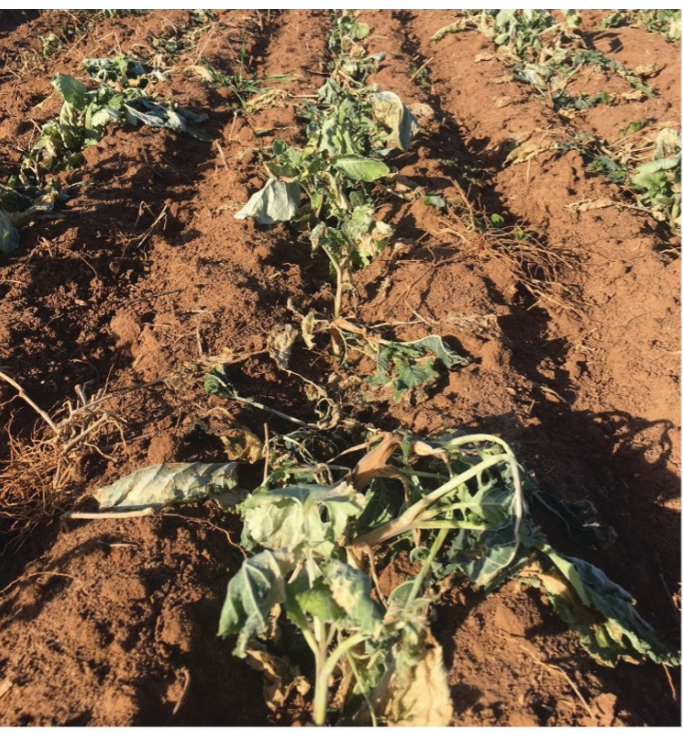

Figure 3. More severe cold damage of carinata during early bolting. This level of damage is expected to reduce stands and yield. Note that aboveground tissue was severely affected, but neither the growing points nor roots died. This field generally grew back from the growing point, but could have resprouted at the crown if the damage was more severe. UF/IFAS West Florida Research and Education Center, Jay, FL.

Credits: M. J. Mulvaney, UF/IFAS 
Table 3. Cumulative hours below temperature thresholds four weeks prior to the date the photo in Figure 3 was taken.

\begin{tabular}{|l|l|}
\hline Planted: & 2-Nov-2017 \\
\hline Photo taken: & 19-Jan-2018 \\
\hline Temperature & Cumulative Hours Below \\
\hline $32^{\circ} \mathrm{F}\left(0^{\circ} \mathrm{C}\right)$ & 196.8 \\
\hline $25^{\circ} \mathrm{F}\left(-3.9^{\circ} \mathrm{C}\right)$ & 63.8 \\
\hline $20^{\circ} \mathrm{F}\left(-6.7^{\circ} \mathrm{C}\right)$ & 14.5 \\
\hline $15^{\circ} \mathrm{F}\left(-9.4^{\circ} \mathrm{C}\right)$ & 0.0 \\
\hline
\end{tabular}

After bolting, freeze damage of the stalk is more problematic (Figure 4). Splitting of the stem may be evident several inches off the ground, but the stalk can freeze without splitting, effectively clogging the vascular tissue later in the season and presenting as a wilted appearance. When this happens, the stem can hollow out at the point of damage. The weakened stem often results in lodging, although some plants will frequently right themselves, giving a "J-stemmed" appearance (Figure 5). The injured stem can serve as an entry point for pests, such as Sclerotinia (leading to Sclerotinia stem rot) and yellowmargined leaf beetles (Microtheca ochroloma Stål) (Figure 6).

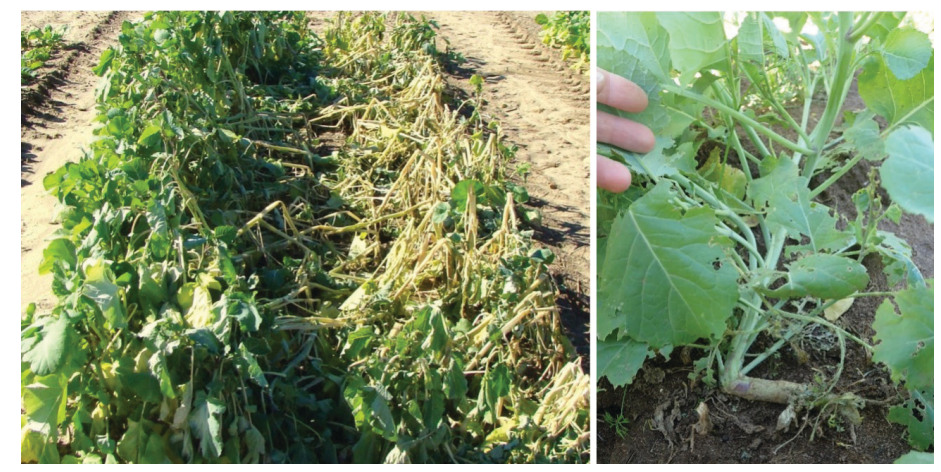

Figure 4. Left: severe freeze damage of carinata after bolting in Quincy, FL. Note growing point damage on the left and lodging on the right. This crop regrew from the crown at an approximated $70 \%$ yield penalty. Replanting after January 15 may be expected to incur at least $50 \%$ yield penalty. UF/IFAS North Florida Research and Education Center, Quincy, FL. Right: Recovery and regrowth after lodging caused by stem weakening during freeze. UF/IFAS West Florida Research and Education Center, Jay, FL.

Credits: Left: R. Seepaul, UF/IFAS. Right: M. J. Mulvaney, UF/IFAS

Table 4. Cumulative hours below temperature thresholds four weeks prior to the date the left photo in Figure 4 was taken.

\begin{tabular}{|l|l|}
\hline Photo taken: & 15-Jan-2014 \\
\hline Temperature & Cumulative Hours Below \\
\hline $32^{\circ} \mathrm{F}\left(0^{\circ} \mathrm{C}\right)$ & 61.8 \\
\hline $25^{\circ} \mathrm{F}\left(-3.9^{\circ} \mathrm{C}\right)$ & 19.3 \\
\hline $20^{\circ} \mathrm{F}\left(-6.7^{\circ} \mathrm{C}\right)$ & 3.5 \\
\hline $15^{\circ} \mathrm{F}\left(-9.4^{\circ} \mathrm{C}\right)$ & 0.0 \\
\hline
\end{tabular}


of the plants suffered mortality. As a highly plastic crop, carinata can promote branching, pod formation, and leaf area to compensate for stand loss, but there is evidence that secondary branches are not as productive as primary branches. It is also important to note that prolonged freeze duration at bolting can weaken carinata stems. This can lead to heavy damage later during the season (at pod fill) as the plant struggles to support heavy growth at the top which can ultimately result in yield loss (Figure 8).

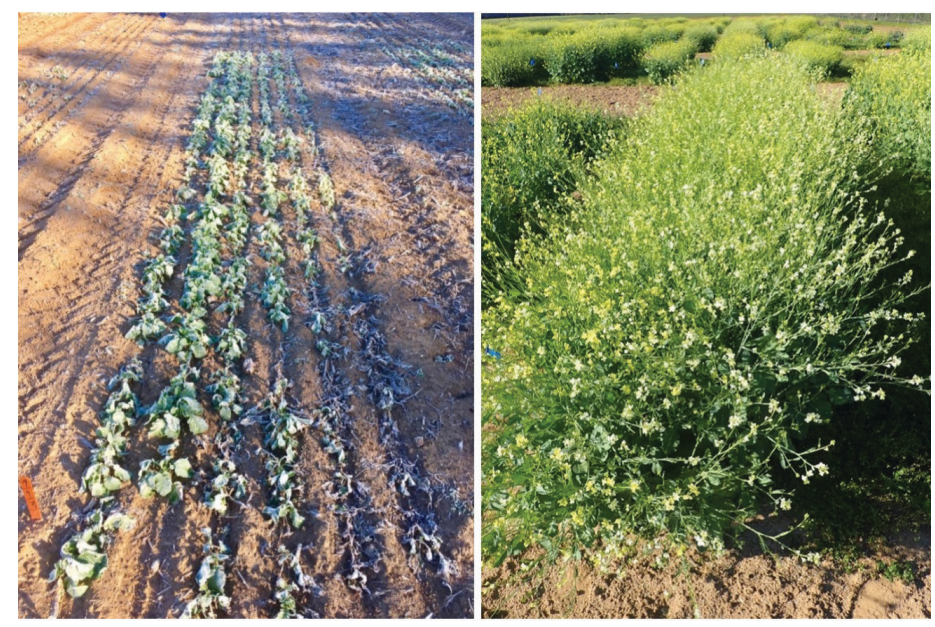

Figure 7. The same carinata plot shown after a hard freeze (left, January 19, 2018) and during flowering (right, March 21, 2018). This plot suffered $25 \%$ mortality. Note that increased branching can fill in the gaps, although secondary branches are not as productive as primary branches. UF/IFAS West Florida Research and Education Center, Jay, FL.

Credits: Left: M. Brown, UF/IFAS. Right: M. J. Mulvaney, UF/IFAS

Table 5. Cumulative hours below temperature thresholds four weeks prior to the date the left photo in Figure 7 was taken.

\begin{tabular}{|l|l|}
\hline Planted: & 16-Nov-2017 \\
\hline Photo taken: & 19-Jan-2018 \\
\hline Temperature & Cumulative Hours Below \\
\hline $32^{\circ} \mathrm{F}\left(0^{\circ} \mathrm{C}\right)$ & 196.8 \\
\hline $25^{\circ} \mathrm{F}\left(-3.9^{\circ} \mathrm{C}\right)$ & 63.8 \\
\hline $20^{\circ} \mathrm{F}\left(-6.7^{\circ} \mathrm{C}\right)$ & 14.5 \\
\hline $15^{\circ} \mathrm{F}\left(-9.4^{\circ} \mathrm{C}\right)$ & 0.0 \\
\hline
\end{tabular}
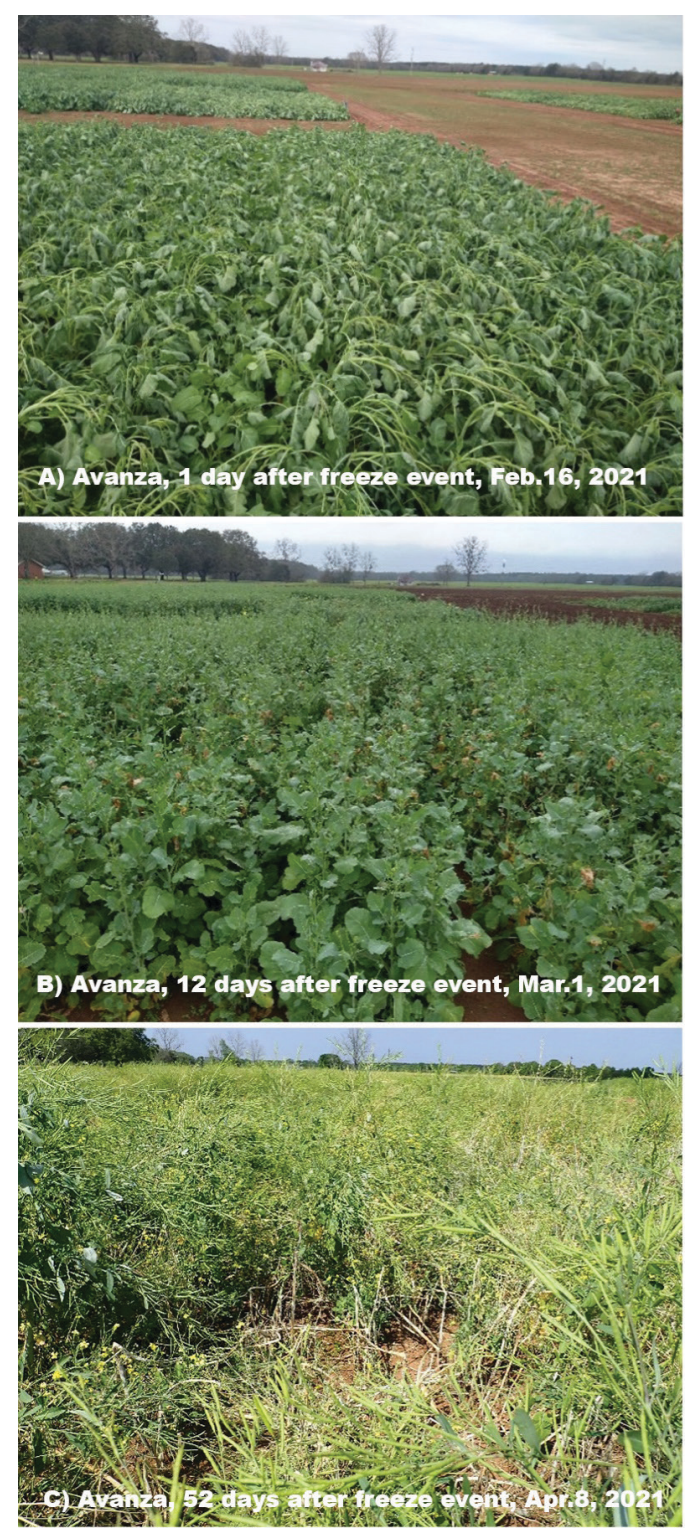

Figure 8. Freeze damage observed a day after a hard freeze event in the commercial variety Avanza at the bolting growth stage (A, February 16, 2021), 12 days after the freeze (B, March 1, 2021) and at pod fill (C, April 8, 2021). This plot suffered 55\% damage at pod fill (note: damage assessment was based on lodging and death of the main stem in the plant). UF/IFAS West Florida Research and Education Center, Jay, FL.

Credits: M. Bashyal, UF/IFAS

Table 6. Cumulative hours below temperature thresholds 12 days prior to the date the middle photo (B) in Figure 8 was taken.

\begin{tabular}{|l|l|}
\hline Planted: & 9-Nov-2021 \\
\hline Top photo taken: & 16-Feb-2021 \\
\hline Middle photo taken: & 1-Mar-2021 \\
\hline Bottom photo taken: & 8-Apr-2021 \\
\hline Temperature & Cumulative Hours Below \\
\hline $32^{\circ} \mathrm{F}\left(0^{\circ} \mathrm{C}\right)$ & 34 \\
\hline $25^{\circ} \mathrm{F}\left(-3.9^{\circ} \mathrm{C}\right)$ & 78 \\
\hline $20^{\circ} \mathrm{F}\left(-6.7^{\circ} \mathrm{C}\right)$ & 0 \\
\hline
\end{tabular}




\section{How to Minimize Risk of Freeze Damage of Carinata}

- A general recommendation is that carinata should be sown approximately six weeks before first frost.

- In the Florida Panhandle, plant carinata during the first two weeks of November. In North Carolina, planting should occur between mid-September and early October. Earlier plantings will reduce yield, and later plantings are more likely to result in small plants at the seedling stage with shallow roots during freeze events. Plants at this stage are more susceptible to freeze damage and may require replanting if the roots freeze. Timely planting allows plants to develop into the rosette stage, when freeze tolerance is greater, during times when the probability of freeze is highest.

- Do not over-apply early-season nitrogen (N). Excessive $\mathrm{N}$ promotes luxuriant growth that is more susceptible to freeze damage. Limit at-plant $\mathrm{N}$ applications to $20 \mathrm{lb} \mathrm{N} / \mathrm{ac}$ or lower. Preliminary results indicate greater freeze damage under higher rates of applied N (Figure 9). Calibrate your spreader so you do not over-apply. Topdress $\mathrm{N}$ applications are typically made at early bolting.

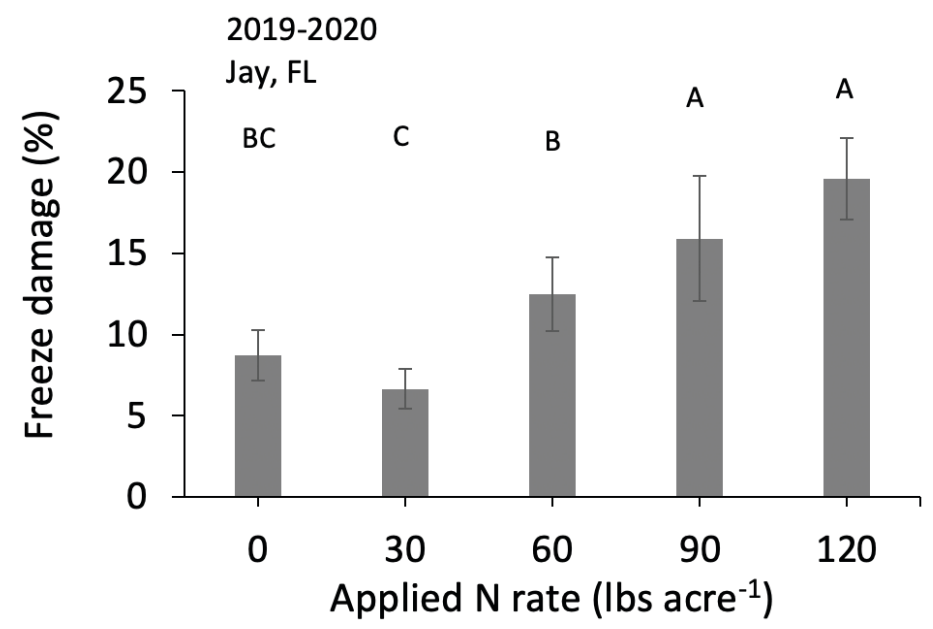

Figure 9. Freeze damage assessment in Brassica carinata under increasing rates of total applied $\mathrm{N}$ in north Florida. Different letters represent significantly different means (LSD, $p=0.05)$. Error bars represent standard errors of mean.

Credits: M. Bashyal, UF/IFAS

Be advised that this is a relatively new crop to the Southeast. Ongoing research and new information will change production recommendations. Additionally, promising new carinata varieties with improved freeze tolerance and yield gains are being developed from the breeding program for commercial production (Figure 10). Check with your local Extension agent for the latest production information.

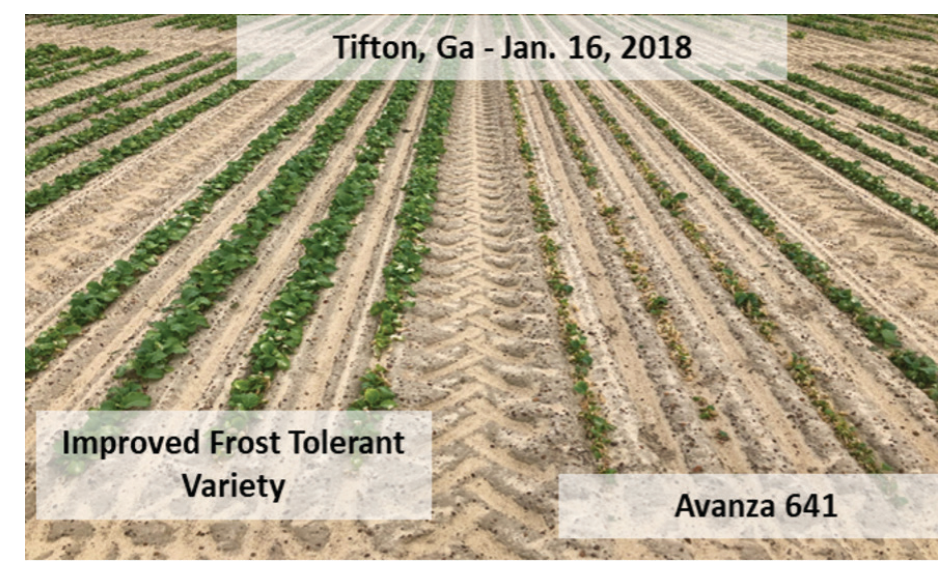

Figure 10. Freeze-tolerant carinata lines derived through breeding programs show promise for tolerating hard freeze events and may become available to the region in the near future.

Credits: Nuseed Co. (previously Agrisoma Biosciences Inc.)

\section{References}

Agrisoma. 2017. Southeastern US 2017-18 Carinata

Management Handbook. https://agrisoma.com/wp-content/ uploads/2018/10/2017_18_SE_Handbook.pdf

Oka, Y. 2010. "Mechanisms of Nematode Suppression by Organic Soil Amendments-A Review." Applied Soil Ecology 44:101-115. https://doi.org/10.1016/j.apsoil.2009.11.003

Seepaul, R., I. M. Small, M. J. Mulvaney, S. George, R. G. Leon, S. V. Paula-Moraes, D. Geller, J. J. Marois, and D. L. Wright. 2019. Carinata, the Sustainable Crop for a Bio-Based Economy: 2018-2019 Production Recommendations for the Southeastern United States. SS-AGR-384. Gainesville: University of Florida Institute of Food and Agricultural Sciences. https://edis.ifas.ufl.edu/ag389

Shen, S. 2019. "Extraction and Polymerization of Bio-Aromatics from Megacrops." MSc thesis. Gainesville: University of Florida. https://ufdc.ufl.edu/UFE0055730/00001

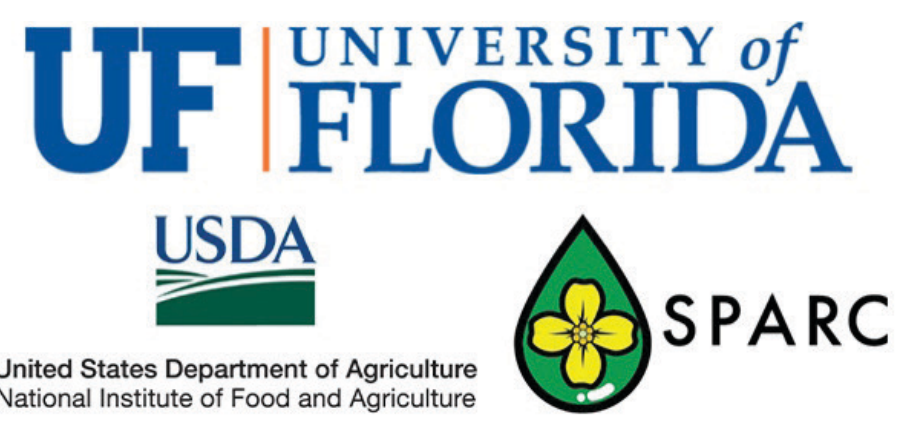

